\title{
小規模建築物に用いる回転貫入杭の支持力特性に関する統計的検討 STATISTICAL STUDY ON BEARING CAPACITY OF SCREW PILE FOR SMALL BUILDINGS
}

\author{
廣瀬 竜也*, 伊藤淳志**, 下平祐司***
}

\section{Tatsuya HIROSE, Atsushi ITO and Yuji SHIMOHIRA}

\begin{abstract}
For estimating the bearing capacity of screw piles which are used for the small building foundations, we collected the loading test data and statistically examined the relations between the ultimate bearing capacity and the conversion $N$-value by the SWS tests. Correlation is comparatively high in the ultimate end bearing capacity with the average conversion $\mathrm{N}$-value within above and below $1 D_{w}\left(D_{w}:\right.$ tip wing diameter) of pile tip. However, the ultimate end bearing capacity and the ultimate frictional resistance of screw pile were smaller than those of straight pile because of disturbance of the surrounding ground by the tip wing in the penetration.
\end{abstract}

Keywords : screw pile, Bearing capacity, Swedish weight sounding test, Small buildings, Vertical load test 回転貫入杭，支持力特性，スウェーデン式サウンディング試験，小規模建築物，鉛直載荷試験

\section{1.はじめに}

戸建て住宅等の小規模建築物の地盤補強を目的として、小口径鋼 管（外径 $\phi 267.4 \mathrm{~mm}$ 以下）の先端に掘削刃と先端翼を溶接または 一体成型し、これを回転して地盤に貫入させる回転貫入杭工法（以 下、“回転貫入杭”と称す）がある。

回転貫入杭の支持力に関しては、国府田ら 1)、大杉・土屋ら 2) 5)、 竹口ら 6)などの研究があり、回転貫入の際の先端翼近傍の土の移動 による貫入メカニズムや、先端翼下部に発生する空洞が杭先端の荷 重一沈下量関係の初期剛性を低下させることなどが明らかになって いる。しかし、これらの研究のほとんどは模型実験に基づいた支持 カメカニズムに関するものであり、現場での実大載荷試験によって 鉛直支持力を地盤定数との関係で検討したものは少ない。

杭の鉛直支持力については、平成 13 年国土交通省告示第 1113 号 （以下、“告示 1113 号” と称寸）に規定されているが、回転貫入杭 に関しては触れられていない。そのため、工法毎に告示 1113 号の 第 6 に従って相当数の載荷試験を実施し、性能評価を経て大臣認定 を取得していることが多い。この際、これらの杭の支持力係数は、 標準貫入試験（以下、“SPT”と称寸）の $N$ 值と粘性土地盤の不擋 乱試料についての一軸圧縮強さ $q_{u}$ に基づいたものと規定されてい る。

しかし、小規模建築物の地盤調查としては、費用、工期および騷 音等の理由により、SPT や不擋乱試料の採取および一軸圧縮試験を 実施することは希である。これに代わるものとして、SPT よりも経
済的で短工期に複数個所の調查が可能なスウェーデン式サウンディ ング試験（JIS A 1221、以下、“SWS 試験”と称寸）が採用される ことが多く、この試験結果より換算 $N$ 值や換算 $q_{u}$ を求め、支持力 算定式に適用している場合がある。また、小規模建築物基礎設計指 針 7)では、SWS 試験結果による換算 $N$ 值や換算 $q_{u}$ に基づく小口径 杭の杭状地盤補強の極限支持力式に、告示 1113 号で示されている 埋込み杭と同じ支持力係数を用いることが提案されているが、その 根拠は示されていない。

以上を背景として、本研究では、戸建て住宅等の小規模建築物の 地盤補強に用いられている回転貫入杭の支持力算定式を確立するこ とを目的として、先端翼形状が 3 タイプの計 15 工法の回転貫入杭 の現場載荷試験結果を収集し、極限支持力度と SWS 試験結果から 評価される換算 $N$ 值との関係について検討する。

\section{2. 検討対象工法の概要}

\section{1 先端翼形状}

回転貫入杭の先端翼の形状の概略図を図 1 に、先端翼形状毎の検 討対象資料の概要を表 1 に示す。同表には、比較対象とした先端翼 の無いストレート型の回転貫入杭工法（以下、“ストレート杭”と称 す）の概要も示した。先端翼の形状は、螺旋状（Type1）、切欠き付 き円盤（Type2）、2 枚の長方形あるいは半円形の鋼板（Type3）で あり、先端翼は杭軸部に溶接もしくは杭軸部と一体成型されている。 軸鋼管の材質は、回転貫入杭、ストレート杭ともに一般構造用炭素

\footnotetext{
本論文の一部は, 地盤工学研究発表会 ${ }^{(i)}$ ，3)，日本建築学会大会注 2 㧍よび地盤工学会シンポジウム注4)に発表した。

* 関西大学大学院Ｇraduate School of Science and Engineering, Kansai University

一般財団法人日本建築総合試験所 修士(工学) General Building Research Corporation of Japan, M. Eng.

** 関西大学環境都市工学部建築学科＼cjkstart准教授·博士 (工学) Assoc. Prof., Dept. of Architecture, Faculty of Environment and Urban Engineering, Kansai

*** 一般財団法人日本建築総合試験所 博士(工学) Geral Building Research Corporation of Japan, Dr. Eng.
} 
鋼鋼管（JIS G 3444）で、先端翼の材質は、Type1 は一般構造用圧 延鋼材（JIS G 3101）、溶接構造用圧延鋼材（JIS G 3106）あるい は溶接構造用鋳鋼品 (JIS G 5102)、Typ2 および Type3 は一般構造 用圧延鋼材あるいは溶接構造用圧延鋼材である。
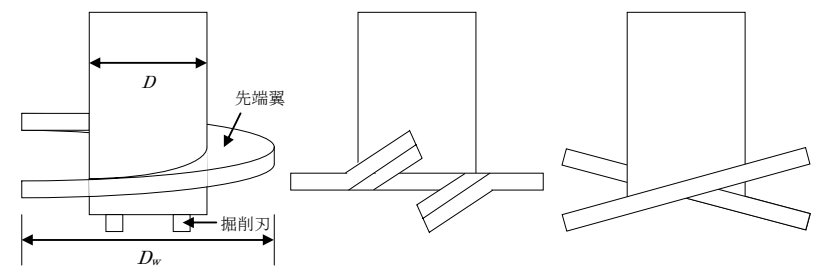

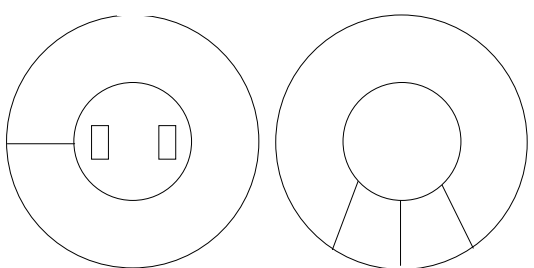

(a) Type1

(b) Type2
図 1 先端翼の形状

表 1 検討対象杭一覧

\begin{tabular}{|c|c|c|c|c|c|c|}
\hline 工法 & $\begin{array}{c}\text { 先端翼の } \\
\text { 形状 }\end{array}$ & 工法数 ${ }^{*}$ & $\begin{array}{c}\text { 軸部径 } \\
D \\
(\mathrm{~mm}) \\
\end{array}$ & $\begin{array}{c}\text { 先端翼径 } \\
D_{W} \\
(\mathrm{~mm}) \\
\end{array}$ & $D_{w} / D$ & $\begin{array}{c}\text { 杭長 } \\
L \\
(\mathrm{~m}) \\
\end{array}$ \\
\hline \multirow{6}{*}{ 回転貫入杭 } & \multirow{2}{*}{ Type1 } & 8 & \multirow{2}{*}{$\begin{array}{l}89.1 \sim \\
267.4\end{array}$} & \multirow{2}{*}{$\begin{array}{c}230 \sim \\
810\end{array}$} & 1.9 & \multirow{2}{*}{$\begin{array}{l}1.9 \sim \\
22.5\end{array}$} \\
\hline & & 5 & & & 4.5 & \\
\hline & \multirow{2}{*}{ Type2 } & 4 & \multirow{2}{*}{$\begin{array}{l}60.5 \sim \\
216.3\end{array}$} & \multirow{2}{*}{$\begin{array}{c}200 \sim \\
500\end{array}$} & 1.6 & \multirow{2}{*}{$\begin{array}{c}1.75 \sim \\
21.5\end{array}$} \\
\hline & & 3 & & & 5.8 & \\
\hline & \multirow{2}{*}{ Type3 } & 3 & \multirow{2}{*}{$\begin{array}{l}76.3 \sim \\
165.2\end{array}$} & \multirow{2}{*}{$\begin{array}{c}200 \sim \\
400\end{array}$} & 1.8 & \multirow{2}{*}{$\begin{array}{l}2.5 \sim \\
18.0\end{array}$} \\
\hline & & 2 & & & 3.1 & \\
\hline \multirow{2}{*}{ ストレート杭 } & \multirow{2}{*}{-} & 4 & \multirow{2}{*}{$\begin{array}{l}89.1 \sim \\
267.4\end{array}$} & \multirow{2}{*}{-} & \multirow{2}{*}{-} & \multirow{2}{*}{$\begin{array}{l}3.0 \sim \\
19.0\end{array}$} \\
\hline & & 3 & & & & \\
\hline
\end{tabular}

*工法数の上段は先端地盤が砂質土、下段は粘性土の数を示す。

\section{2 . 2 極限鉛直支持力式}

本研究における支持力係数は、極限鉛直支持力 $R_{u}$ の算定式とし

て SWS 試験結果に基づいて定義した式(1)に従って求める。

$R_{u}=\alpha_{S W} \overline{N^{\prime}} A_{p}+\left(\beta_{S W} \overline{N_{s}^{\prime}} L_{s}+\gamma_{S W} \overline{N_{c}^{\prime}} L_{c}\right) \Psi$

ここに、

$R_{u} \quad$ : 極限鉛直支持力 $(\mathrm{kN})$

$\alpha_{S W}$ : 先端抵抗に関する支持力係数

$\beta_{S W}$ : 砂質土地盤での周面摩擦抵抗に関する支持力係数

$\gamma_{S W} \quad$ : 粘性土地盤での周面摩擦抵抗に関する支持力係数

$\overline{N^{\prime}}$ : 杭先端の $N^{\prime}$ の平均值で、下記の 3 種類を検討対象とした。 $\overline{N_{1}^{\prime}}$ : 回転貫入杭は、杭先端下方 $1 D_{w} \sim$ 上方 $1 D_{w}$ （以下、 \pm $1 D_{w}$ と表記)、ストレート杭は、杭先端下方 $1 D \sim$ 上方

$1 D$ (以下、 $\pm 1 D$ と表記) の範囲における $N^{\prime}$ の平均值 $\overline{N_{2}^{\prime}}$ : 回転貫入杭は、杭先端下方 $2 D_{w} \sim$ 上方 $1 D_{w}$ (以下、$2 D_{w}+1 D_{w}$ と表記)、ストレート杭は、杭先端下方 $2 D \sim$ 上方 $1 D$ (以下、 $-2 D+1 D$ と表記) の範囲における $N^{\prime}$ の平均值

$\overline{N_{4}^{\prime}}$ : 回転貫入杭は、杭先端下方 $4 D_{w} \sim$ 上方 $1 D_{w}$ （以下、-
$4 D_{w}+1 D_{w}$ と表記)、ストレート杭は、杭先端下方 $4 D \sim$ 上方 $1 D$ (以下、 $-4 D+1 D$ と表記) の範囲における $N^{\prime}$ の平均值

$D_{w}$ : 先端翼径 $(\mathrm{m})$

$D$ : 軸部径 $(\mathrm{m})$

$\overline{N_{s}^{\prime}}$ : 杭軸部が砂質土に接する部分の $N^{\prime}$ の平均值

$\bar{N}_{c}^{\prime}$ : 杭軸部が粘性土に接する部分の $N^{\prime}$ の平均值

$N^{\prime}$ :SWS 試験結果による換算 $N$ 值で、式(2)、(3) 8) による。

砂質土 : $N^{\prime}=2 W_{S W}+0.067 N_{S W}$

粘性土: $N^{\prime}=3 W_{S W}+0.05 N_{S W}$

$W_{S W}: \mathrm{SWS}$ 試験の荷重 $(\mathrm{kN})$

$N_{S W}$ : SWS 試験の貫入量 $1 \mathrm{~m}$ 当たりの半回転数

$A_{p} \quad$ : 杭先端有効断面積 $\left(\mathrm{m}^{2}\right)$

回転貫入杭 : $A_{p}=D_{W}{ }^{2} \pi / 4$

ストレート杭 : $A_{p}=D^{2} \pi / 4$

$L_{s} \quad$ : 杭軸部が砂質土地盤に接する長さ $(\mathrm{m})$

$L_{c} \quad$ : 杭軸部が粘性土地盤に接する長さ (m)

$\Psi \quad$ : 杭軸部の周長 $(\mathrm{m})$

$\overline{N^{\prime}}$ の算定範囲のうち、杭先端上方位置 $\left(+1 D_{w}\right.$ あるいは $\left.+1 D\right)$ については、載荷試験における先端支持力が杭先端 $+1 D_{\text {w }}$ あいは $+1 D$ に貼付したひずみゲージの測定值から求めた軸力としている ことを考慮した。したがって、本研究における先端支持力には、杭 先端 $+1 D_{w}$ あるいは $+1 D$ の位置から杭先端までの周面摩擦力も含 まれていることになる。杭先端下方位置については、既往の検討結 果等を参考に設定した。すなわち、(1)建築基礎構造設計指針 9)の場 所打ちコンクリート杭および埋込み杭の平均 $N$ 值の算定範囲が杭 先端 $\pm 1 D$ であること、(2)小椋 ${ }^{10}$ )により場所打ち杭は杭先端 $-2 D+$ $1 D$ の平均 $N$ 值が支持力評価の精度が最も高いことが示されている こと、(3)山崎 ${ }^{11)}$ により埋込み杭は杭先端 $-2 \sim-4 D$ の $N$ 值が杭先 端 $-1 D$ の $N$ 值よりも小さい場合、杭先端 $-4 D$ までの平均 $N$ 值が 支持力評価の精度が最も高いことが示されていること、(4)佐伯ら ${ }^{12)}$ により杭先端一 $4 D$ までの $N$ 值に梁度により重み付けを行って平均 $N$ 值を算定する方法が提案されていること、などである。

なお、 $\overline{N^{\prime}}$ は、算定範囲内の $N^{\prime}$ の単純平均とした。また、地盤 を砂質土地盤（碩質土地盤を含む、以下同様）および粘性土地盤に 分けて検討を行っているが、 $\overline{N_{2}^{\prime}}$ および $\overline{N_{4}^{\prime}}$ については、先端地盤 が砂質土地盤あるいは粘性土地盤と称していても、その算定範囲に 異なる土質を含んでいる場合もある。

回転貫入杭の杭先端有効断面積 $A_{p}$ は、先端翼下部の接地圧分布 (例えば、台形分布) を考慮して翼部の面積に低減係数を乗じる工 法もあるが、本研究では、先端翼および軸部先端の水平面への全投 影面積と定義した。また、ストレート杭の杭先端有効断面積 $A_{p}$ は、 軸部先端の水平面への全投影面積と定義した。

鉛直載荷試験は、地盤工学会基準「杭の押込み試験方法」13)に準 拠して、全て多サイクル段階載荷方式で行われている。また、極限 鉛直支持力は、杭先端沈下量が $D_{w}$ (回転貫入杭の場合) あるいは $D$ (ストレート杭の場合)の $10 \%$ に達した時点の荷重と定義し、この 荷重以上の載荷荷重を所定の時間（通常 30 分）保持できているも のを検討対象データとした。 


\section{3． 先端抵抗に関する支持力特性}

\section{1 SWS 試験の換算 $N$ 值による検討}

同一現場、同一深度で施工された回転貫入杭とストレート杭の先 端荷重 $P_{p}$-先端沈下量 $S_{p}$ 関係の 1 例を図 2 に示す。軸部径は回転 貫入杭、ストレート杭ともに $139.8 \mathrm{~mm}$ 、回転貫入杭の先端翼径は $350 \mathrm{~mm}$ (Type1)、杭先端深度は GL-11.4m、先端地盤の土質は砂 質土である。同図において、ストレート杭は、 $S_{p}$ が $10 \mathrm{~mm}$ 付近で $P_{p}-S_{p}$ 曲線が折れ曲がっているが、回転貫入杭は、 $S_{p}$ が $0.1 D_{w}$ を 超えても明確な折れ点は認められない。これらの傾向は、土屋ら 4)

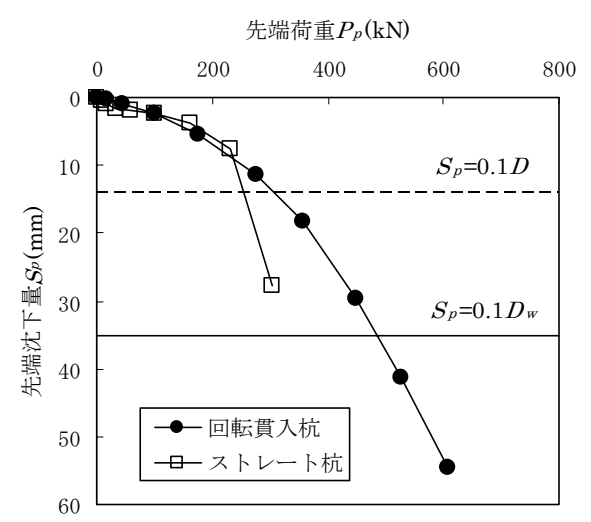

図 2 先端荷重一先端沈下量関係
による模型実験でも認められている。

回転貫入杭の極限先端支持力度 $q_{p}-\bar{N}^{\prime}$ 関係を先端地盤別に図 3 および図 4 に、また回転貫入杭およびストレート杭の $q_{p} / \overline{N^{\prime}}$ に関 する統計的な検討結果（以下、“統計結果”と称す）を表 2 および 表 3 にそれぞれ示した。

砂質土地盤、粘性土地盤ともに、回転貫入杭の $q_{p} / \overline{N^{\prime}}$ の平均值は、 $\overline{N_{1}^{\prime}}>\overline{N_{2}^{\prime}}>\overline{N_{4}^{\prime}}$ の順に大きい。これは図 5 に示すように、 $\overline{N_{2}^{\prime}}$ およ び $\bar{N}_{4}^{\prime}$ に、 $\overline{N_{1}^{\prime}}$ に比べて比較的大きな值の $N^{\prime}$ が含まれているためて ある。ただし、データのばらつきを示す変動係数は、 $\overline{N_{1}^{\prime}}<\overline{N_{2}^{\prime}}<\overline{N_{4}^{\prime}}$ の順に小さい。なお、ストレート杭の $q_{p} / \overline{N^{\prime}}$ の平均值は、両先端 地盤ともに $\overline{N_{2}^{\prime}}$ の場合が最も大きな值となっており、回転貫入杭の 場合の 2 倍以上の值となっている。

図 3 および図 4 を見ると、先端翼のタイプの違いによる $q_{p} / \overline{N^{\prime}}$ の 差はそれほど顕著ではないが、Type2 が比較的大きく、Type1 が比 較的小さい傾向が認められる。そこで、先端翼の形状毎の $q_{p} / \overline{N_{1}^{\prime}}$ に 関する統計結果を表 4 に示した。 $q_{p} / \overline{N_{1}^{\prime}}$ の平均值は、両先端地盤と もに、Type2 が最も大きく、以下 Type3、Type1 の順となっている。 この要因として、先端翼の形状の違いによる先端地盤の攪乱度合の 差が考えられる。その他、土屋等 3)の Type1 の先端翼形状の模型実 験で確認されている先端翼の下部に生じる空洞について、先端翼の 形状によってその大きさが異なることも一因と推察される。

次に、回転貫入杭の軸部径に対する先端翼径の比 $D_{w} / D$ が支持力

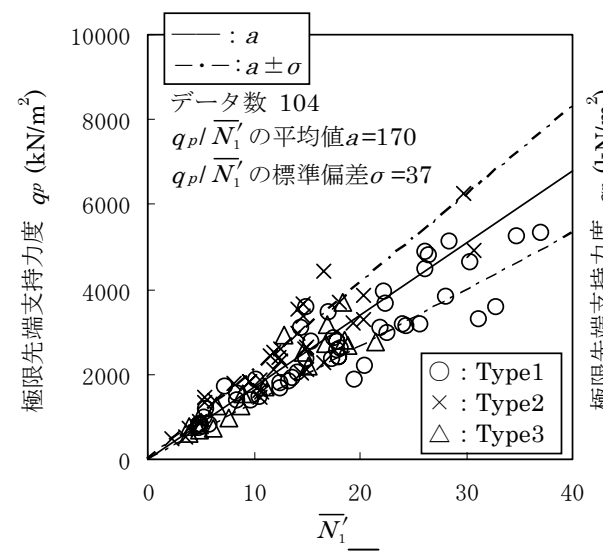

(a) $q_{p}-\overline{N_{1}^{\prime}}$ 関係

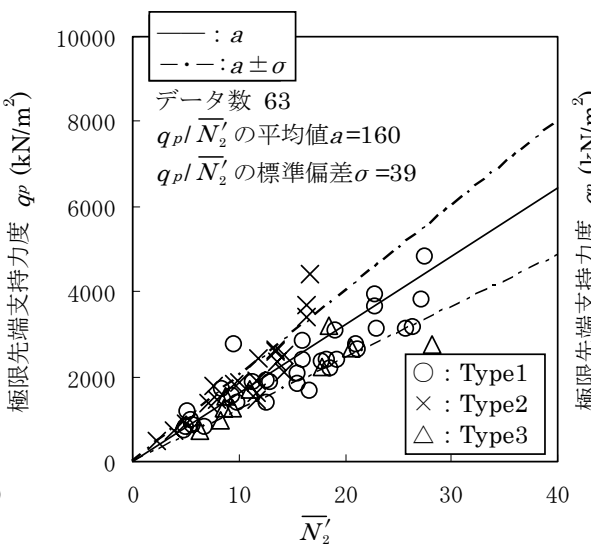

(b) $q_{p}-\bar{N}_{2}^{\prime}$ 関係

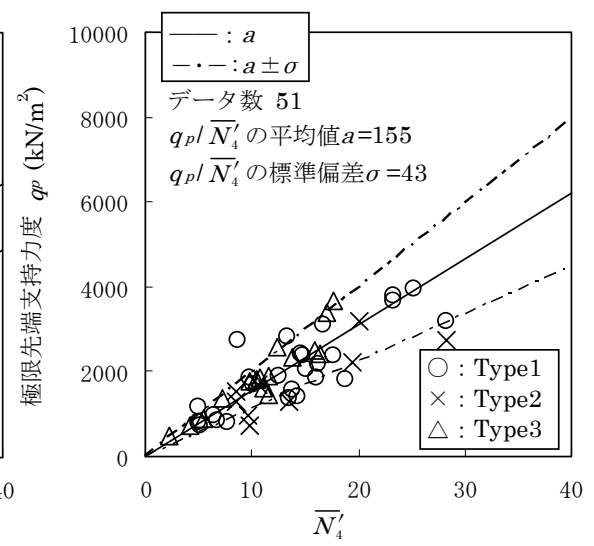

(c) $q_{p}-\bar{N}_{4}^{\prime}$ 関係

図 3 回転貫入杭の極限先端支持力度 $q_{p}$-杭先端平均換算 $N$ 值 $\bar{N}^{\prime}$ 関係（砂質土）

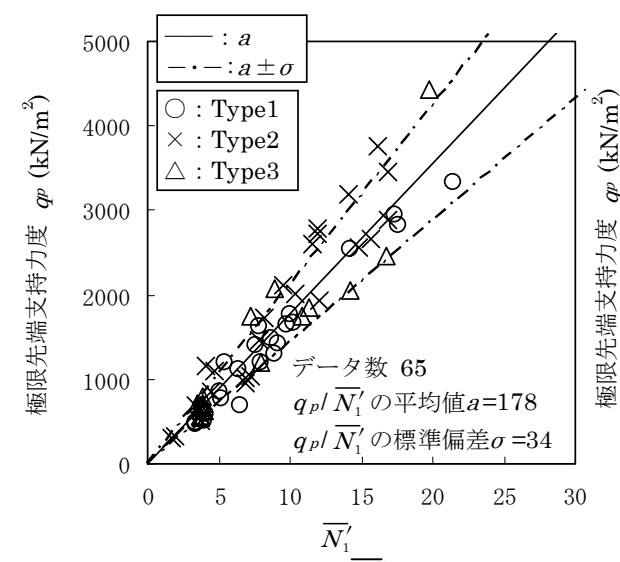

(a) $q_{p}-\overline{N_{1}^{\prime}}$ 関係

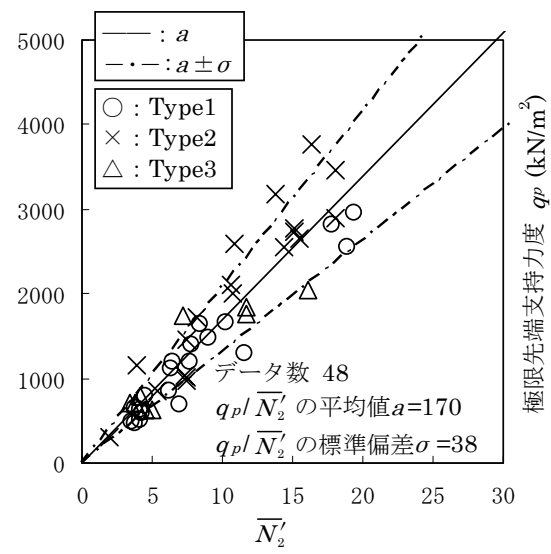

(b) $q_{p}-\bar{N}_{2}^{\prime}$ 関係

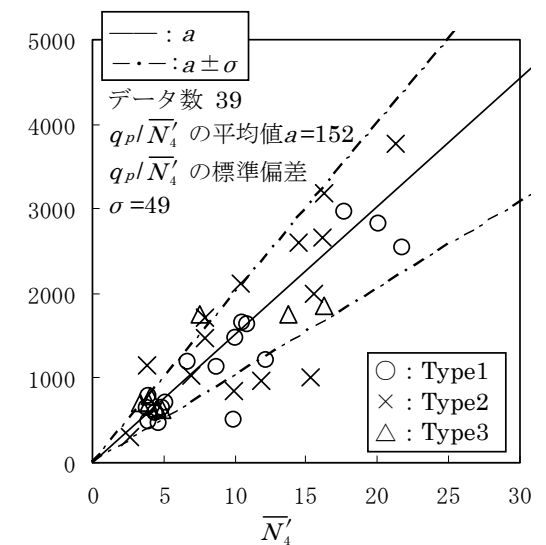

(c) $q_{p}-\bar{N}_{4}^{\prime}$ 関係

図 4 回転貫入杭の極限先端支持力度 $q_{p}$-杭先端平均換算 $N$ 值 $\bar{N}^{\prime}$ 関係（粘性土） 
表 $2 q_{p} / \overline{N^{\prime}}$ に関する統計結果（砂質土）

\begin{tabular}{|c|c|c|c|c|c|}
\hline \multirow{4}{*}{ 工法 } & $\overline{N^{\prime}}$ & データ数 & $\begin{array}{c}\text { 平均値 } \\
a\end{array}$ & $\begin{array}{c}\text { 標準偏差 } \\
\sigma\end{array}$ & 変動係数 \\
\hline \multirow{4}{*}{ 回転貫入杭 } & $\overline{N_{1}^{\prime}}$ & $104(15)$ & 170 & 37 & 0.22 \\
\cline { 2 - 6 } & $\overline{N_{2}^{\prime}}$ & $63(14)$ & 160 & 39 & 0.24 \\
\cline { 2 - 6 } & $\overline{N_{4}^{\prime}}$ & $51(13)$ & 155 & 43 & 0.28 \\
\hline \multirow{3}{*}{ ストレート杭 } & $\overline{N_{1}^{\prime}}$ & $26(4)$ & 342 & 69 & 0.20 \\
\cline { 2 - 6 } & $\overline{N_{2}^{\prime}}$ & $20(4)$ & 356 & 53 & 0.15 \\
\cline { 2 - 6 } & $\overline{N_{4}^{\prime}}$ & $13(4)$ & 334 & 46 & 0.14 \\
\hline
\end{tabular}

( )内は工法数を示す。

表 $3 q_{p} / \overline{N^{\prime}}$ に関する統計結果（粘性土）

\begin{tabular}{|c|c|c|c|c|c|}
\hline \multirow{4}{*}{ 工法 } & $\overline{N^{\prime}}$ & データ数 & $\begin{array}{c}\text { 平均值 } \\
a\end{array}$ & $\begin{array}{c}\text { 標隻偏差 } \\
\sigma\end{array}$ & 変動係数 \\
\hline \multirow{3}{*}{ 回転貫入杭 } & $\overline{N_{1}^{\prime}}$ & $65(10)$ & 178 & 34 & 0.19 \\
\cline { 2 - 6 } & $\overline{N_{2}^{\prime}}$ & $48(9)$ & 170 & 38 & 0.22 \\
\cline { 2 - 6 } & $\bar{N}_{4}^{\prime}$ & $39(8)$ & 152 & 49 & 0.32 \\
\hline \multirow{3}{*}{ ストレート杭 } & $\overline{N_{1}^{\prime}}$ & $17(3)$ & 358 & 56 & 0.16 \\
\cline { 2 - 6 } & $\overline{N_{2}^{\prime}}$ & $17(3)$ & 361 & 56 & 0.16 \\
\cline { 2 - 6 } & $\bar{N}_{4}^{\prime}$ & $9(2)$ & 345 & 73 & 0.21 \\
\hline
\end{tabular}

( )内は工法数を示す。

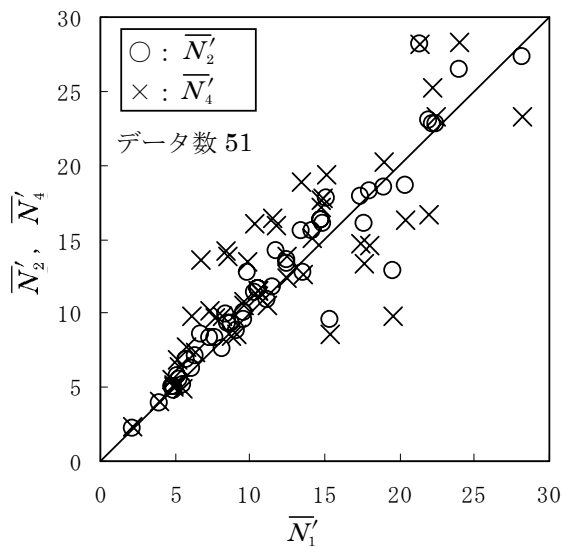

(a) 砂質土

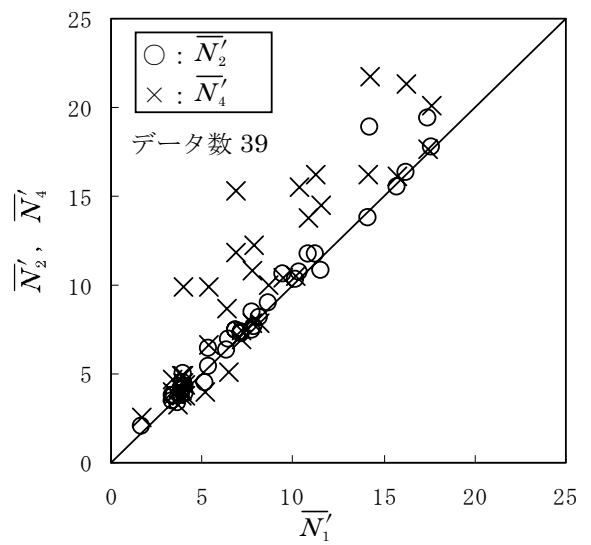

(b) 粘性土

図 $5 \overline{N_{1}^{\prime}}-\overline{N_{2}^{\prime}}, \overline{N_{4}^{\prime}}$ 関係

に及ぼす影響を検討するため、 $q_{p} / \overline{N_{1}^{\prime}}$ と $D_{w} / D$ の関係を図 6 に示し た。図中には、全データの最小二乗法による回帰式と相関係数 $R$ を 示したが、 $D_{w} / D$ と $q_{p} / \overline{N_{1}^{\prime}}$ の間にはほとんど相関が認められない。 これは、 $D_{w} / D$ が大きくなるほど、先端翼の耐力と剛性を高めるた
表 4 回転貫入杭の先端翼の形状毎の $q_{p} / \overline{N_{1}^{\prime}}$ に関する統計結果

\begin{tabular}{|c|c|c|c|c|c|}
\hline 土 & $\begin{array}{c}\text { 先端翼の } \\
\text { 形状 }\end{array}$ & データ数 & $\begin{array}{c}\text { 平均值 } \\
a\end{array}$ & $\begin{array}{c}\text { 標準偏差 } \\
\sigma\end{array}$ & 変動係数 \\
\hline \multirow{2}{*}{$\begin{array}{c}\text { 質 } \\
\text { 土 }\end{array}$} & Type1 & $49(8)$ & 156 & 32 & 0.21 \\
\cline { 2 - 6 } & Type2 & $36(4)$ & 198 & 45 & 0.23 \\
\hline \multirow{2}{*}{ 粘 } & Type3 & $19(3)$ & 162 & 28 & 0.17 \\
\cline { 2 - 6 } 性 & Type1 & $24(5)$ & 162 & 24 & 0.15 \\
\cline { 2 - 6 } 土 & Type3 & $24(3)$ & 193 & 37 & 0.19 \\
\hline
\end{tabular}

( )内は工法数を示す。

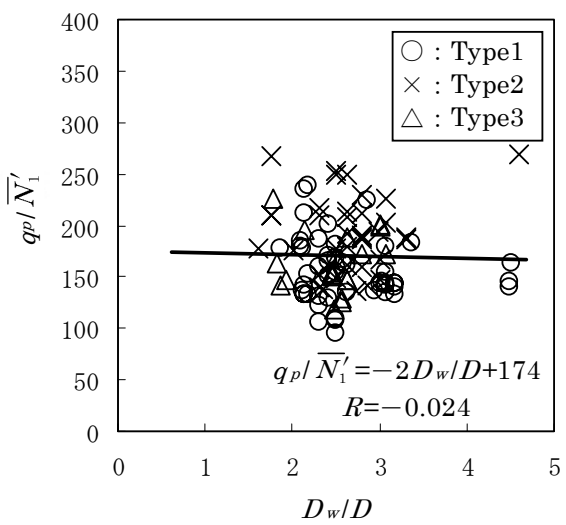

(a) 砂質土

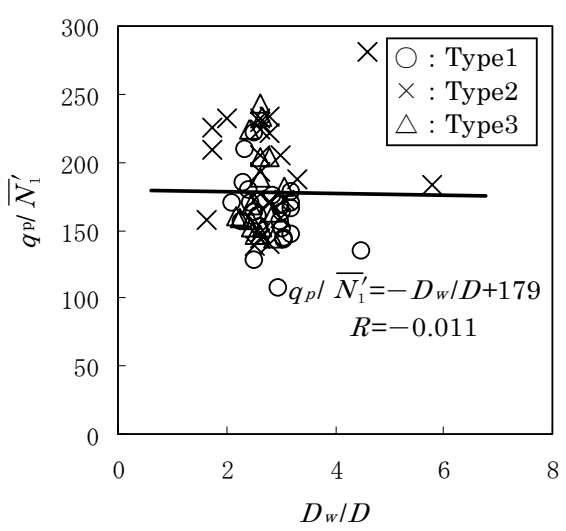

(b) 粘性土

図 $6 \quad q_{p} / \overline{N_{1}^{\prime}}-D_{w} / D$ 関係

めに先端翼の厚さが厚くなっており、先端翼の変形による支持力低 下がさほど表れなかったためと考えられる。

小規模建築物基礎設計指針 7)には、杭状地盤補強の先端部の下部 地盤が粘性土の場合の極限先端支持力 $R_{p}$ の算定式として、式(4)が 示されている。

$R_{p}=6 c A_{p}$

ここに、

$c:$ 粘着力 $\left(\mathrm{kN} / \mathrm{m}^{2}\right) 、 \mathrm{SWS}$ 試験に基づく場合には式(5)による。

$$
c=q_{u} / 2=\left(45 W_{S W}+0.75 N_{S W}\right) / 2
$$

式(5)の右辺の ( )内は一軸圧縮強さ $q_{u}\left(\mathrm{kN} / \mathrm{m}^{2}\right)$ の換算式であり、 粘性土の $N^{\prime}$ の算定式(3)を 15 倍したものとなっている。したがっ て、前述した粘性土の $q_{p} / \overline{N_{1}^{\prime}}$ の平均值 178 を $15 / 2$ で除することに より、 $q_{p} / c=23.8$ となる。これは、式(4)による $q_{p}=R_{p} / A_{p}=6 c$ に比 
べて、およそ 4 倍の值となっている。回転貫入杭の場合、SWS 試 験結果より式(5)で $c$ を推定し、さらに式(4)で $q_{p}$ を算定することは、 かなり過小評価になるといえる。

\section{2 SPTの $N$ 值による検討}

前節で対象とした載荷試験結果のうち、SPT の $N$ 值が測定され ているデータについて、回転貫入杭の極限先端支持力度 $q_{p}$ 一杭先端 平均 $N$ 值 $\bar{N}$ 関係を先端地盤毎に図 7 および図 8 に、 $q_{p} / \bar{N}$ の統計 結果を表 5 に示す。ここで、杭先端平均 $N$ 值は、換算 $N$ 值で評価 した場合に極限支持力度との相関性が最も高い杭先端 $\pm 1 D_{W}$ 間の測 定值の単純平均とした。したがって、平均範囲内の $N$ 值の測定点数 は、 1 または 2 となっている。なお、図 7 には、建築基礎構造設計 指針 9)に示されている打込み杭、場所打ちコンクリート杭および埋 込み杭の極限先端支持力度の算定式も示しておいた。各種杭の支持 力係数は、平均值を安全側に丸めたものであるが、排土杭に分類さ れる回転貫入杭の $q_{p} / \bar{N}$ の平均值は、非排土杭である場所打ちコン クリート杭と埋込み杭の場合の中間の值となった。これは、回転貫

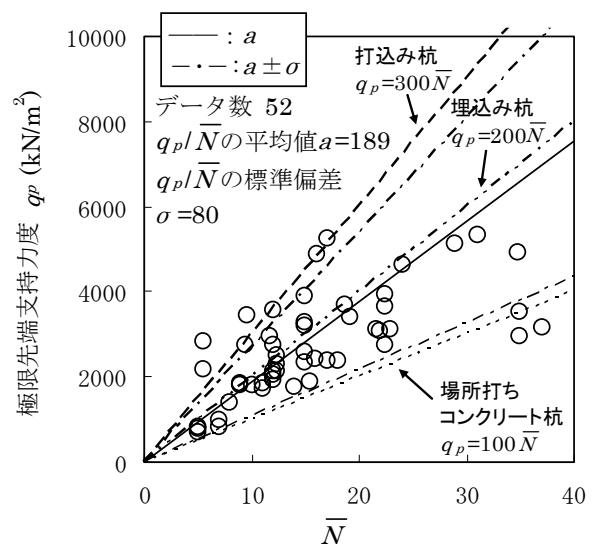

図 7 回転貫入杭の極限先端支持力度 $q_{p}$-杭先端平均 $N$ 值 $\bar{N}$ 関係 (砂質土)

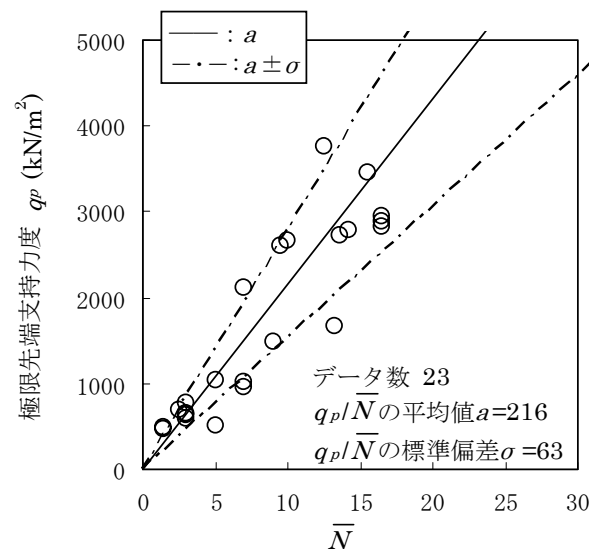

図 8 回転貫入杭の極限先端支持力度 $q_{p}$-杭先端平均 $N$ 值 $\bar{N}$ 関係 (粘性土)

表 5 回転貫入杭の $q_{p} / \bar{N}$ に関寸る統計結果

\begin{tabular}{|c|c|c|c|c|}
\hline 土質 & データ数 & $\begin{array}{c}\text { 平均值 } \\
a\end{array}$ & $\begin{array}{c}\text { 標準偏差 } \\
\sigma\end{array}$ & 変動係数 \\
\hline 砂質土 & $52(7)$ & 189 & 80 & 0.42 \\
\hline 粘性土 & $23(3)$ & 216 & 63 & 0.29 \\
\hline
\end{tabular}

()内は工法数を示す。
入杭の先端翼による先端地盤の攪乱の影響のほか、埋込み杭におけ る先端根固め部による拡径の影響や場所打ちコンクリート杭の実際 の径が設計径より大きいことなどの影響も考えられる。

砂質土地盤における $q_{p} / \bar{N}$ の平均値は、 $q_{p} / \overline{N_{1}^{\prime}}$ の平均值（表 2 参照) とほぼ同等であるが、粘性土地盤における $q_{p} / \bar{N}$ の平均值は、 $q_{p} / \overline{N_{1}^{\prime}}$ の平均值（表 3 参照）に比べて大きい。これは、図 9 に示す ように、砂質土地盤では $\bar{N}$ と $\bar{N}_{1}^{\prime}$ が平均ではほぼ等しいのに対し、 粘性土地盤では $\bar{N}$ が $\overline{N_{1}^{\prime}}$ に比べて平均では小さいことが反映され ている。また、変動係数については $q_{p} / \bar{N}$ の方がかなり大きくなっ ている。これは、 $N$ 值が通常は深さ $1 \mathrm{~m}$ 毎のデータしか得られない のに対して、SWS 試験による換算 $N$ 值は $25 \mathrm{~cm}$ 毎にデータが得ら れるためと考えられる。このことを確認するために、N值が得られ ているデータについて、 $N$ 值の測定深度と同じ深度の $N^{\prime}$ から平均 換算 $N$ 值 $\bar{N}_{1 N}^{\prime}$ を求め、 $q_{p} / \overline{N_{1}^{\prime}}$ と $q_{p} / \bar{N}_{1 N}^{\prime}$ について比較した結果を 表 6 に示す。 $q_{p} / \bar{N}_{1 N}^{\prime}$ の変動係数は、 $q_{p} / \bar{N}_{1}^{\prime}$ の変動係数の 1.5 倍程 度となっており、SWS 試験によって $25 \mathrm{~cm}$ 毎に換算 $N$ 值が得られ

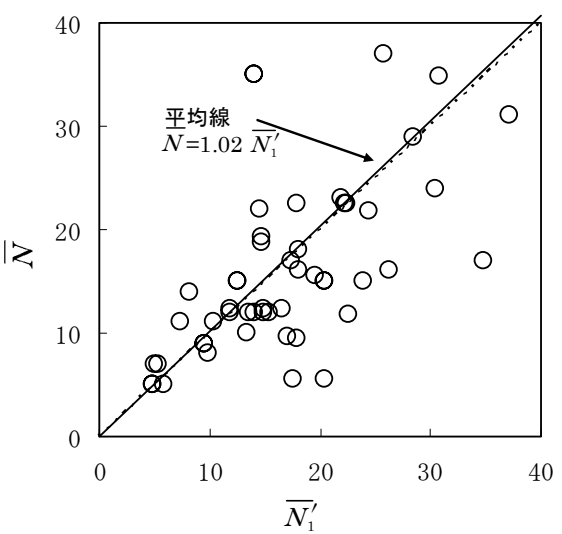

(a) 砂質土

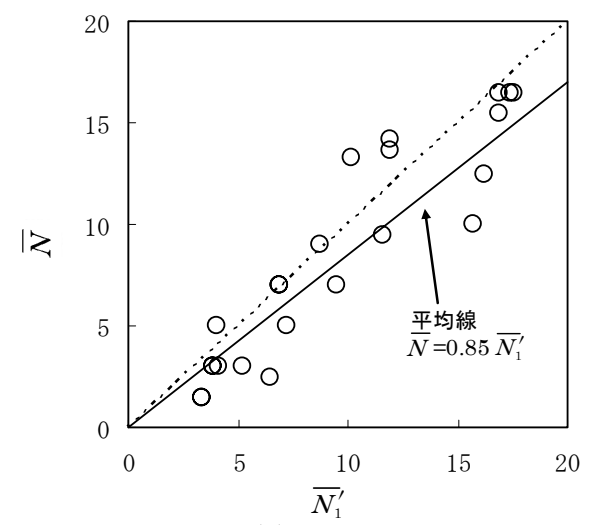

(b) 粘性土

図 $9 \overline{N_{1}^{\prime}}-\bar{N}$ 関係

表 $6 q_{p} / \overline{N_{1}^{\prime}}$ と $q_{p} / \bar{N}_{1 N}^{\prime}$ に関する統計結果

\begin{tabular}{|c|c|c|c|c|c|}
\hline \multirow{2}{*}{ 土質 } & $\overline{N^{\prime}}$ & データ数 & $\begin{array}{c}\text { 平均值 } \\
a\end{array}$ & $\begin{array}{c}\text { 標準偏差 } \\
\sigma\end{array}$ & 変動係数 \\
\hline \multirow{2}{*}{ 砂質土 } & $\overline{N_{1}^{\prime}}$ & $41(6)$ & 169 & 36 & 0.21 \\
\cline { 2 - 6 } & $\overline{N_{1 N}^{\prime}}$ & $41(6)$ & 173 & 52 & 0.30 \\
\hline \multirow{2}{*}{ 粘性土 } & $\overline{N_{1}^{\prime}}$ & $23(3)$ & 170 & 36 & 0.21 \\
\cline { 2 - 7 } & $\overline{N_{1 N}^{\prime}}$ & $23(3)$ & 161 & 45 & 0.28 \\
\hline
\end{tabular}

( )内は工法数を示す。 
ることが地盤定数の適切な評価に寄与していることが確認できた。 したがって、本研究で対象としている小径の回転貫入杭に対しては SPT よりも SWS 試験の方が地盤定数を適切に評価出来ているとい える。

\section{4. 周面摩擦抵抗に関する支持力特性}

\section{1 SWS 試験の換算 $N$ 值による検討}

杭周面の土質が砂質土および粘性土における回転貫入杭の極限周 面摩擦力度 $f_{s}, f_{c}$-杭周面平均換算 $N$ 值 $\bar{N}_{s}^{\prime}, \bar{N}_{c}^{\prime}$ 関係を図 10 に、

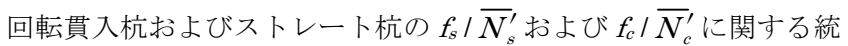
計結果を表 7 に示寸。砂質土では、ストレート杭の $f_{s} / \overline{N_{s}^{\prime}}$ の平均值 は回転貫入杭の約 1.4 倍、粘性土のそれは約 2.0 倍となっている。 先端翼によって施工時に杭軸部周面地盤が大きく乱されているもの と考えられ、特に粘性土で顕著である。

回転貫入杭の先端翼の形状毎の $f_{s} / \overline{N_{s}^{\prime}}$ および $f_{c} / \overline{N_{c}^{\prime}}$ に関する統

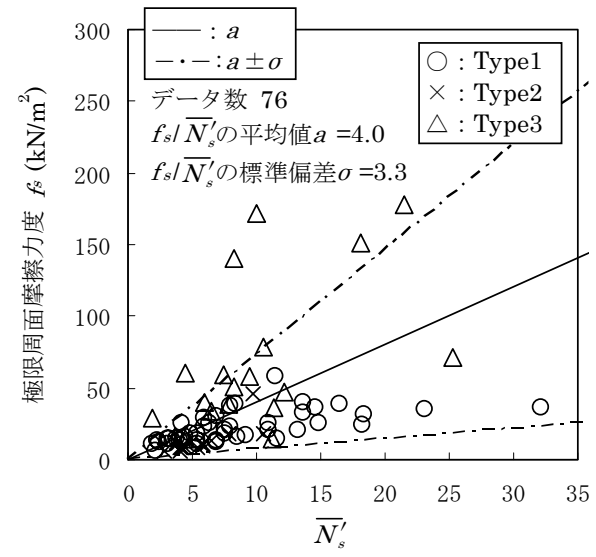

(a) 砂質土

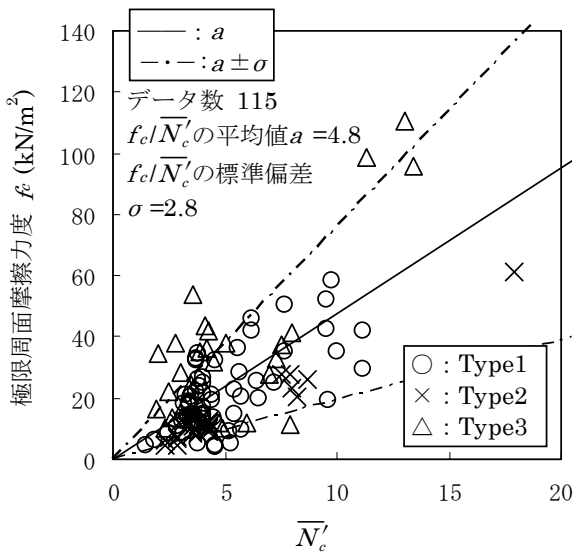

(b) 粘性土

図 10 極限周面摩擦力度 $f_{s}, f_{c}$-杭周面平均換算 $N$ 值 $\overline{N_{s}^{\prime}}, \overline{N_{c}^{\prime}}$ 関係

表 $7 f_{s} / \overline{N_{s}^{\prime}}$ および $f_{c} / \overline{N_{c}^{\prime}}$ に関する統計結果

\begin{tabular}{|c|c|c|c|c|c|}
\hline \multirow{2}{*}{ 土質 } & 工法 & データ数 & $\begin{array}{c}\text { 平均值 } \\
a\end{array}$ & $\begin{array}{c}\text { 標準偏差 } \\
\sigma\end{array}$ & 変動係数 \\
\hline \multirow{2}{*}{ 砂質土 } & 回転貫入杭 & $76(7)$ & 4.0 & 3.3 & 0.83 \\
\cline { 2 - 7 } & ストレート杭 & $52(4)$ & 5.5 & 1.4 & 0.25 \\
\hline \multirow{2}{*}{ 粘性土 } & 回転貫入杭 & $115(7)$ & 4.8 & 2.8 & 0.58 \\
\cline { 2 - 7 } & ストレート杭 & $55(4)$ & 9.7 & 3.5 & 0.36 \\
\hline
\end{tabular}

( )内は法数を示す。
計結果を土質毎に表 8 に示す。 $f_{s} / \overline{N_{s}^{\prime}}$ および $f_{c} / \overline{N_{c}^{\prime}}$ の平均値は、 Type3 が他のタイプと比べてかなり大きくなっており、貫入時の地 盤の乱れが比較的小さいと考えることができる。ただし、工法数が 1 つのみであり、変動係数が大きいため、さらにデータを蓄積して 検討が必要である。

表 8 回転貫入杭の先端翼の形状毎の

$f_{s} / \bar{N}_{s}^{\prime}$ および $f_{c} / \bar{N}_{c}^{\prime}$ に関する統計結果

\begin{tabular}{|c|c|c|c|c|c|}
\hline $\begin{array}{c}\text { 土 } \\
\text { 質 }\end{array}$ & $\begin{array}{c}\text { 先端翼の } \\
\text { 形状 }\end{array}$ & データ数 & $\begin{array}{c}\text { 平均值 } \\
a\end{array}$ & $\begin{array}{c}\text { 標準偏差 } \\
\sigma\end{array}$ & 変動係数 \\
\hline \multirow{2}{*}{$\begin{array}{c}\text { 質 } \\
\text { 土 }\end{array}$} & Type1 & $42(4)$ & 3.1 & 1.4 & 0.45 \\
\cline { 2 - 6 } & Type2 & $15(2)$ & 2.2 & 0.8 & 0.36 \\
\cline { 2 - 6 } 粘 & Type3 & $19(1)$ & 7.5 & 4.8 & 0.64 \\
\cline { 2 - 6 } 性 & Type1 & $59(4)$ & 4.5 & 1.9 & 0.42 \\
\cline { 2 - 6 } 土 & Type2 & $28(2)$ & 2.8 & 0.6 & 0.21 \\
\cline { 2 - 6 } & Type3 & $28(1)$ & 7.2 & 3.8 & 0.53 \\
\hline
\end{tabular}

( )内は法数を示す。

小規模建築物基礎設計指針 7)には、杭状地盤補強の極限周面摩擦 力度 ${ }_{d}$ の算定式として、砂質土地盤については式(6)が、粘性土地 盤については式(7)が示されている。

砂質土： $\tau_{d}=10 N / 3$

粘性土： $\tau_{d}=c$

砂質土地盤の場合、 $N$ は、SWS 試験に基づく場合には式(2)によ る。回転貫入杭の $f_{s} / \bar{N}_{s}^{\prime}$ の平均値は 4.0 (表 7 参照) であり、式(6) の $\tau_{d} / N=10 / 3$ より大きい。しかし、式(6)の $\tau_{d} / N$ は、データのば らつきを考慮して平均值を安全側に低減した值であり、建築基礎構 造設計指針 ${ }^{14)}$ に示されている $75 \%$ 超過係数 $(=a-0.67 \sigma)$ を $f_{s} / \bar{N}_{s}^{\prime}$ について求めると $f_{s} / \overline{N_{s}^{\prime}}$ の $75 \%$ 超過係数は 1.8 となり、式(6)の 0.54 倍の $\tau_{d}$ となる。粘性土地盤の場合、 $c$ は、先端地盤と同様に、SWS 試験に基づく場合には式(5)によるので、回転貫入杭の $f_{c} / \overline{N_{c}^{\prime}}$ の平均 值 4.8 (表 7 参照）を $15 / 2$ で除すると、 $f_{c} / c=0.64$ となる。これら の結果より、SWS 試験結果より小規模建築物基礎設計指針に示され ている方法に従って式(6)および式(7)で極限摩擦力度を算定するの は、先端支持力の場合とは逆に過大評価となるといえる。

\section{2 SPTのN值による検討}

前節で対象とした載荷試験結果のうち、 $N$ 值が測定されているデ 一夕について、回転貫入杭の極限周面摩擦力度 $f_{s}$ 一杭周面平均 $N$ 值 $\bar{N}_{s}$ 関係を図 11 に示す。同図には、建築基礎構造設計指針 9)に示さ れている各種杭の極限周面摩擦力度の算定式も示した。回転貫入杭 の $f_{s} / \bar{N}_{s}$ の平均值は、埋込み杭の支持力係数とほぼ同等の值となっ ているが、各種杭の場合は、データのばらつきを考慮して平均値を 安全側に低減させたものであるため、回転貫入杭の $f_{s} / \bar{N}_{s}$ について 前述の $75 \%$ 超過係数を求めると 1.7 となり、各種杭の場合より小さ くなった。これは、施工時の先端翼による杭軸部周面地盤の攪乱の 影響によると考えられる。

$f_{s} / \bar{N}_{s}$ の平均值 2.4 は、表 7 で示した回転貫入杭の $f_{s} / \bar{N}_{s}^{\prime}$ の平均 值 4.0 よりかなり小さくなった。図 12 に $\bar{N}_{s}^{\prime}$ と $\bar{N}_{s}$ との関係を示し たが、ばらつきはあるものの $\bar{N}_{s}$ の方が大きい傾向にあることが分 かる。 


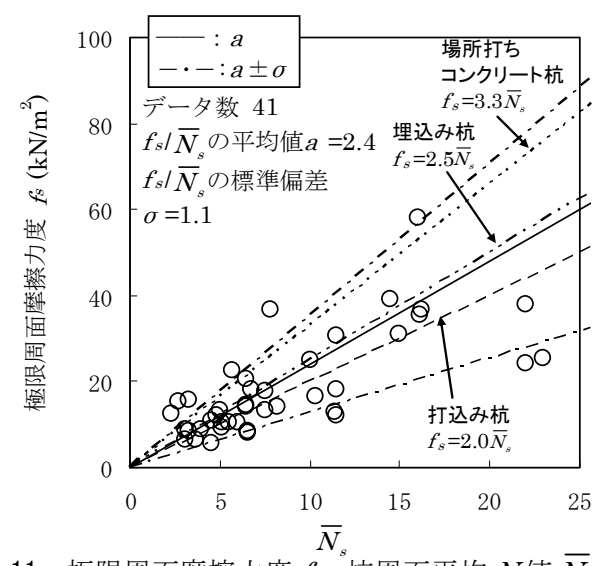

図 11 極限周面摩擦力度 $f_{s}-$ 杭周面平均 $N$ 值 $\bar{N}_{s}$ 関係

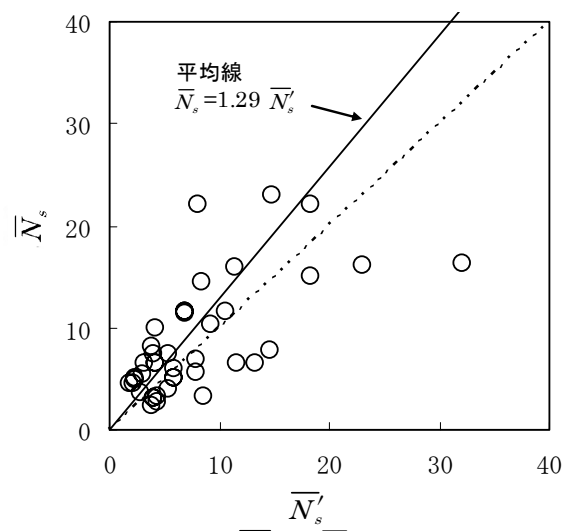

図 $12 \overline{N_{s}^{\prime}}-\bar{N}_{s}$ 関係

\section{5.まとめ}

戸建て住宅等の小規模建築物の地盤補強に用いられている小口径 回転貫入杭の支持力算定式を確立することを目的として、3タイプ の先端翼形状を有する回転貫入杭工法の載荷試験データを対象に、 先端支持力度および周面摩擦力度と SWS 試験結果から求められる 換算 $N$ 值との関係について統計的に検討した。得られた主要な知見 は、以下のとおりである。

(1) 回転貫入杭の極限先端支持力を先端沈下量が先端翼径 $D_{w}$ の 10 $\%$ に達した時の先端荷重と定義し、極限先端支持力度 $q_{p}$ と 3 種類の 先端平均換算 $N$ 值との関係を検討した結果、先端地盤が砂質土（碩 質土を含む)、粘性土の場合ともに杭先端下方 $1 D_{W} \sim$ 上方 $1 D_{W}$ 間の 平均換算 $N$ 值 $\overline{N_{1}^{\prime}}$ が他の範囲の值より比較的小さいが、相関性が最 も高く、その平均值は以下のとおりであった。

砂質土 : $q_{p}=170 \bar{N}_{1}^{\prime}$

粘性土 : $q_{p}=178 \overline{N_{1}^{\prime}}$

(2) 3 種類の先端翼形状別の $q_{p} / \overline{N_{1}^{\prime}}$ の平均值は、切欠き付き円盤

(Type2) の場合が他の形状のものよりも大きくなった。

(3) 回転貫入杭の極限周面摩擦力度 $f_{s}$ (周面地盤が砂質土) および $f_{c}$ （同粘性土）と平均換算 $N$ 值 $\overline{N_{s}^{\prime}}$ および $\overline{N_{c}^{\prime}}$ との関係の平均值は以 下のとおりであった。

砂質土 : $f_{s}=4.0 \overline{N_{s}^{\prime}}$

粘性土 : $f_{c}=4.8 \overline{N_{c}^{\prime}}$

(4) 3 種類の先端翼の形状別の $f_{s} / \bar{N}_{s}^{\prime}$ および $f_{c} / \bar{N}_{c}^{\prime}$ の平均值は、 2 枚の鋼板（Type3）の場合が他の形状のものよりもかなり大きくな った。ただし、データ数が少ないため、さらにデータを蓄積して検
討が必要である。

(5) SPT による杭先端下方 $1 D_{W} \sim$ 上方 $1 D_{W}$ 間の平均 $N$ 值 $\bar{N}$ と $q_{p}$ と の関係は、SWS 試験による同区間での平均換算 $N$ 值 $\overline{N_{1}^{\prime}}$ と $q_{p}$ との 関係よりも変動係数が大きかった。 $N$ 值と同一深度での換算 $N$ 值 $\bar{N}_{1 N}^{\prime}$ を求めても、 $\bar{N}_{1 N}^{\prime}$ と $q_{p}$ との関係は、 $\overline{N_{1}^{\prime}}$ と $q_{p}$ との関係よりも 変動係数が大きく、本研究で対象としている平均換算 $N$ 值が 30 程 度までの地盤における回転貫入杭の支持力に対しては、測定間隔の 小さい SWS 試験の方が地盤定数をより適切に評価できるものと考 えられる。

\section{謝辞}

本報告にあたっては、(一財)日本建築総合試験所の建築技術性能 証明を取得した各企業から詳細な試験データを提供して頂いた。こ こに記して、感謝の意を表します。

\section{参考文献}

1）国府田誠，佐藤秀人，刑部徹，国司基，永田誠，平田尚，田村昌仁：螺旋 羽を持つ回転貫入杭の貫入および支持力に関する基礎的研究, 日本建築学 会構造系論文集，No.601，pp.91-98，2006.3

2）大杉富美一，土屋勉，島田正夫，吉田勝之：大型加圧土槽を利用した回転 貫入模型杭の貫入実験, 日本建築学会構造系論文集, No.591, pp.69-75, 2005.5

3）土屋勉，中沢楓太，島田正夫 : 回転貫入杭の羽根近傍地盤の観察に基づく 貫入メカニズムの検討，日本建築学会技術報告集，第 13 巻，第 25 号, pp.73-76, 2007.6

4）土屋勉，大杉富美一，中沢楓太，島田正夫 : 回転貫入杭の貫入・支持力特 性に関する模型実験，日本建築学会構造系論文集，No.620，pp.75-80, 2007.10

5）池田篤則，土屋勉，島田正夫，中沢楓太 : 回転貫入杭の支持層に対する根 入れ効果に関する実験的研究, 日本建築学会構造系論文集, Vol76, No.651, pp.951-956, 2010.5

6）竹口昌弘, 中谷昌一, 井落久貴, 前田良刀, 龍田昌毅, 他 : 回転杭の群杭 効果に関する研究（その 1 ），（その 2)，第 41 回地盤工学研究発表会発 表講演集，pp.1459-1462，2006.7

7）日本建築学会：小規模建築物基礎設計指針, p.186, 2008.

8）地盤工学会 : 地盤調査の方法と解説, p.331， 2013.

9）日本建築学会 : 建築基礎構造設計指針, pp.205, 2001 .

10）小椋仁志 : 場所打ち杭の先端平均 $\mathrm{N}$ 值の平均範囲に関する検討, 日本建 築学会大会学術講演梗概集，B-1，pp.629-630，2001.9

11）山崎雅弘：埋込み杭の極限先端支持力評価のための等価 $\mathrm{N}$ 值, 日本建築 学会大会学術講演梗概集，B-1，pp.485-486，2002.8

12）佐伯英一郎，岩松浩一，木下雅敬：Non-Displacement Pile の先端支持 力推定のための地盤の「平均 $\mathrm{N}$ 值」に関する解析的一考察, 日本建築学会 構造系論文集，No.535，pp.87-94，2000.9

13）地盤工学会：杭の押込み試験方法・同解説，杭の鉛直載荷試験方法・同 解説－第 1 回改訂版 - pp.23-59，2002

14）日本建築学会 : 建築基礎構造設計指針，p.214，2001

注

注 1）廣瀬竜也，下平祐司：スウェーデン式サウンディング試験結果に基づ く回転貫入杭の支持力係数, 第 42 回地盤工学研究発表会発表講演集, pp.1343-1344, 2007.7

注 2）廣瀬竜也，下平祐司：注 1）と同名（その 2），日本建築学会大会学術 講演梗概集，pp.379-380，2007.8

注 3）廣瀬竜也，下平祐司：注 1）と同名（その 3），第 43 回地盤工学研究 発表会発表講演集，pp.1283-1284，2008.7

注 4）廣瀬竜也，下平祐司：スウェーデン式サウンディング試験による地盤 評価に基づく螺旋状先端翼付き小口径回転貫入杭の支持力係数，最近の开 ウンディング技術と地盤評価シンポジウム発表論文集，pp.7-12，2009.10

（2013年11月28日原稿受理，2014年 3 月31日採用決定） 